\title{
In vitro and in vivo anticancer properties of a Calcarea carbonica derivative complex (M8) treatment in a murine melanoma model
}

\author{
Fernando SF Guimarães', Lucas F Andrade', Sharon T Martins', Ana PR Abud', Reginaldo V Sene', \\ Carla Wanderer ${ }^{1}$, Inés Tiscornia ${ }^{2}$, Mariela Bollati-Fogolín², Dorly F Buchi ${ }^{1}$, Edvaldo S Trindade ${ }^{1 *}$
}

\begin{abstract}
Background: Melanoma is the most aggressive form of skin cancer and the most rapidly expanding cancer in terms of worldwide incidence. Chemotherapeutic approaches to treat melanoma have had only marginal success. Previous studies in mice demonstrated that a high diluted complex derived from Calcarea carbonica (M8) stimulated the tumoricidal response of activated lymphocytes against B16F10 melanoma cells in vitro.

Methods: Here we describe the in vitro inhibition of invasion and the in vivo anti-metastatic potential after M8 treatment by inhalation in the B16F10 lung metastasis model.

Results: We found that M8 has at least two functions, acting as both an inhibitor of cancer cell adhesion and invasion and as a perlecan expression antagonist, which are strongly correlated with several metastatic, angiogenic and invasive factors in melanoma tumors.

Conclusion: The findings suggest that this medication is a promising non-toxic therapy candidate by improving the immune response against tumor cells or even induce direct dormancy in malignancies.
\end{abstract}

\section{Background}

Melanoma represents a significant worldwide public health risk and, from the standpoint of incidence, is the fastest growing of all cancer types. Malignnant melanoma is the most aggressive form of skin cancer, with a mortality rate that has risen about $2 \%$ annually since 1960. Although early stage melanoma can be cured surgically, once melanoma metastasizes to major organs (stage IV), it is almost always incurable [1]. There are few chemotherapeutic agents available for treating metastatic melanoma, and those that have been used have all yielded unsatisfactory results. No single chemotherapeutic agent currently offers a response rate greater than $25 \%$, and treatment is invariably accompanied by significant side effects, including myelosuppression, nausea and emesis [2-4].

\footnotetext{
* Correspondence: estrindade@ufpr.br

'Laboratório de Pesquisa em Células Inflamatórias e Neoplásicas Depto de Biologia Celular, Setor de Ciências Biológicas, Federal University of Paraná,
} Brazil
Malignant transformation could be associated with general enzymatic changes leading to increased proteolytic and fibrinolytic activity in tumor cells. The significance of angiogenesis in tumor development and metastasis is well established, and it was previously confirmed that a significant correlation exists between tumor angiogenesis and the ability of a melanoma to metastasize [5]. It has been observed that heparan sulfate proteoglycan expression, especially perlecan expression, is a prerequisite for melanoma tumor growth and metastasis [6,7].

Immunotherapy remains the subject of intense investigation in both adjuvant and advanced disease settings, and attempts are being made to target melanoma defense mechanisms that blunt the effectiveness of host immune responses [8]. Many natural compounds have been extensively studied to determine a possible antitumor effect. Our previous studies have demonstrated that a high diluted natural complex activates macrophages both in vivo and in vitro [9-11]. Moreover, that natural complex was neither toxic nor mutagenic [12].

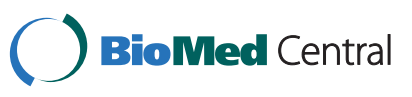

(c) 2010 Guimarães et al; licensee BioMed Central Ltd. This is an Open Access article distributed under the terms of the Creative Commons Attribution License (http://creativecommons.org/licenses/by/2.0), which permits unrestricted use, distribution, and reproduction in any medium, provided the original work is properly cited. 
Similarly, an improvement of the immune response of treated mice has been demonstrated in studies with Sarcoma-180, including a significant infiltration of lymphoid cells, granulated tissue, fibrosis development around the tumor, sarcoma size reduction and an increase in the number of circulating leukocytes, such as $\mathrm{B}, \mathrm{NK}$ and $\mathrm{CD}^{+}$cells [13]. These results suggest that the medication has a direct or indirect action on hematopoiesis. A subsequent microscopic study of bone marrow cells showed that monocytic lineage $\left(C D 11 b^{+}\right)$and stromal cells (adherent cells) were activated by treatment [14-16]. A previous study with an in vitro model showed that a specific high diluted complex derived from Calcarea carbonica and associations (here defined as M8 in the Materials and Methods section) activated lymphocytes even without direct contact with macrophages. A co-culture with macrophages and lymphocytes in the presence of M8 promoted stimulation of lymphocytes, resulting in an enhanced tumoricidal performance against a very aggressive lineage of melanoma cells [17].

We previously reported that M8 showed a promising capacity to stimulate immune cells against melanoma cells in vitro. In the present work we aimed to study the effects of M8 in vivo using a melanoma metastasis mouse model. We assessed blood and bone marrow cells immunophenothyping, tumor histopathology, immunohistochemistry, and ultrastructural analysis.

\section{Methods \\ M8 complex}

High diluted natural complexes represent a new form of immunomodulatory therapy and follow Hahnemann's ancient homeopathic techniques for dilution. Mother tinctures were purchased from authorized agencies sanctioned by the Brazilian Health Ministry. These agencies assure the quality (endotoxin free) and physico-chemical composition of their products. Starting from the original mother tincture - an ethanolic extract in this case several dynamizations/succussion (shaking) and serial dilutions in distilled water were performed. The medication used to treat in vitro and in vivo models was a complex matrix obtained from Calcarea carbonica $\mathrm{CH} 5$ with associations, comprised of a $10 \%-20 \%$ concentration of each compound obtained after vigorous shaking. In addition to Calcarea carbonica, the final solution contained Aconitum napellus, Arsenicum album, Asa foetida, Conium maculatum, Ipecacuanha, Phosphorus, Rhus tox, Silicea, Sulphur, and Thuya occidentalis, all in decimal dilutions of Hahnemann $(\mathrm{dH})$ in distilled water. The resulting aqueous solution was colorless and odorless, and had $1 \%$ alcohol concentration. This complex as well its vehicle (hydroalcoholic solution) used as control were sterilized by filtration through $0.22 \mu \mathrm{m}$ MILLEX
GV Durapore PVDF membranes (Millipore, Billerica, MA, USA), maintained at room temperature and vigorously shaken (succussed) immediately before each treatment. Since all experiments were performed in a double blind and randomized manner, the initial code applied for this studied complex (M8) remains in the Results/ Discussion sections of this article.

\section{Animals}

For in vivo experiments, 2-3 month old male C57BL/6 mice were purchased from Central Animal House of the Federal University of Paraná (UFPR). All recommendations of the National Law (No. 6.638, November, 5, 1979) for scientific management of animals were followed and the Institutional Animal Care Committee of UFPR approved all related practices. All experiments were performed at least three times in quadruplicate and data analysis was performed in a double-blinded manner. Experiments were carried out at Laboratório de Pesquisa em Células Neoplásicas e Inflamatórias, UFPR, Brazil, and at Cell Biology Unit, IPMon, Uruguay.

\section{Cell lines}

\section{B16F10 cells}

Murine melanoma cells (B16F10 - ATCC: CRL-6475; mouse melanoma cell), were used for this study. Cells were maintained in DMEM containing 10\% FBS, $1 \mathrm{U} /$ $\mathrm{mL}$ penicillin, $1 \mu \mathrm{g} / \mathrm{mL}$ streptomycin, and $2.5 \mu \mathrm{g} / \mathrm{mL}$ amphotericin at $37^{\circ} \mathrm{C}$ in a humidified $5 \% \mathrm{CO}_{2}$ atmosphere.

\section{MxRage 7 cells}

Transformed murine embryonic fibroblasts consist of an indicator cell line in which Cre-recombinase is driven by the IFN-inducible Mx1 promoter that, when activated, deletes a stop cassette upstream of the eGFP coding region, resulting in the expression of eGFP. The percentage of eGFP expressing cells, determined by fluorescence activated cell sorting (FACS), accurately correlates to the amount of type I IFN added to the culture [18]. This cell line was maintained at $32^{\circ} \mathrm{C}$ in a humidified 5\% $\mathrm{CO}_{2}$ atmosphere, using DMEM (GIBCO, Invitrogen, Carlsbad, CA, USA) supplemented with $10 \%$ FBS (GIBCO).

\section{HT29}

Human colon-rectal cancer cells (ATCC: HTB-38) were stably transfected with the pNF- $\kappa$ B-hrGFP Plasmid from the PathDetect Signal Transduction Pathway cis-Reporting Systems Kit (Stratagene) Briefly, subconfluent HT29 cells were transfected with pNF- $\kappa \mathrm{B}-\mathrm{hrGFP}$ plasmid using Lipofectamine 2000 (Invitrogen) and selected with hygromycin. After two weeks, cells were stimulated for $24 \mathrm{~h}$ with a pro-inflammatory cocktail $(25 \mathrm{ng} / \mathrm{mL}$ TNF$\alpha, 1.25 \mathrm{ng} / \mathrm{mL}$ IL- $1 \beta$ and $3.75 \mathrm{ng} / \mathrm{mL} \mathrm{IFN}-\gamma)$ and GFP positive cells were sorted with a MoFlo cell sorter 
(Dako, Carpinteria, CA). This sorted cell line was maintained in RPMI (GIBCO) containing 10\% FBS, $1 \mathrm{U} / \mathrm{mL}$ penicillin, $1 \mu \mathrm{g} / \mathrm{mL}$ streptomycin at $37^{\circ} \mathrm{C}$ in a humidified $5 \% \mathrm{CO}_{2}$ atmosphere.

All in vitro experiments were performed at $37^{\circ} \mathrm{C}$ in a humidified $5 \% \mathrm{CO}_{2}$ atmosphere for $48 \mathrm{~h}$. All treatments were administered to log-phase growing cells and the different assayed conditions were divided into: a) cells without treatment (control culture conditions, named "Control"); b) cells treated with vehicle (1\% hydroalcoholic solution, named "Vehicle"); or c) cells treated with M8 (named "M8"). An initial dose of $20 \%$ of M8 treatment was administered to the cells and, after $24 \mathrm{~h}$, a reinforcement dose of $1 \%$ was administered according to a previous standard treatment protocol $[10,16]$.

\section{Experiments on in vitro reporter cells (MxRAGE 7 and HT29-pNF- $\kappa$ B-hrGFP)}

The reporter cell lines MxRAGE 7 and HT29-pNF- $\kappa$ BhrGFP are routinely used at CBU (IPMon) to screen natural or synthetic compounds that interfere with type I IFN signaling pathway and/or modulate NF- $\kappa \mathrm{B}$ activity. For the IFN assay, exponentially growing MxRage 7 cells were seeded in a 96-well plate and grown for $24 \mathrm{~h}$ at $32^{\circ} \mathrm{C}$. The cells were then cultured for $48 \mathrm{~h}$ in presence or absence of fixed amounts of murine IFN- $\alpha 11$, with or without the vehicle or M8. Finally, cells were harvested using trypsin, resuspended in PBS and stained with 7-AAD to identify dead cells. Ten thousand events were acquired and analyzed on a CyAn ${ }^{\text {Ts }}$ ADP Flow Cytometer (Dako, Carpinteria, CA) using Summit v4.3 software. For the NF- $\kappa \mathrm{B}$ activation assay, exponentially growing HT29 pNF- $\kappa$ B-hrGFP cells were treated cultured for $24 \mathrm{~h}$ in absence or presence of $3 \mathrm{ng} / \mathrm{mL}$ TNF$\alpha$, with or without the vehicle or M8 complex, and the percentage of positive GFP cells and the viability were determined using CyAn ${ }^{\mathrm{Tm}}$ ADP Flow Cytometer (Dako, Carpinteria, CA) and Summit v4.3 software.

\section{In vitro $\mathrm{B} 16 \mathrm{~F} 10$ cell experiments}

Invasion activity of melanoma cells was assayed in a transwell cell culture chamber as previously described [19], with some modifications. Briefly, polyvinyl-pyrrolidone-free polycarbonate inserts with an $8.0 \mu \mathrm{m}$ pore size (Corning-Costar, Cambridge, MA, USA) were precoated with $5 \mu \mathrm{g}$ of fibronectin on the reverse side and dried at room temperature. Matrigel (containing laminin, collagen type IV, heparan sulfate proteoglycan and entactin from BD Pharmigen, San Diego, CA, USA) was diluted to $500 \mu \mathrm{g} / \mathrm{mL}$ with cold PBS, applied to the upper surface of the filter ( $5 \mu \mathrm{g} /$ filter), and dried at room temperature. Log-phase growing B16F10 cultures were harvested by trypsin treatment, washed twice and re-suspended to give a final concentration of
$2.0 \times 10^{6} \mathrm{cel} / \mathrm{mL}$ in serum free DMEM medium supplemented with $0.1 \%$ bovine serum albumin (BSA, SigmaAldrich Chemical Co., St. Louis, MO, USA). Cell suspensions $(100 \mu \mathrm{l})$ were added to the upper compartment of the insert chamber and incubated for $6 \mathrm{~h}$ at $37^{\circ}$ $\mathrm{C}$ in a humidified $5 \% \mathrm{CO}_{2}$ atmosphere in the presence or absence (control) of M8 or its vehicle. Cells derived from the different assayed conditions were processed for scanning electron microscopy (SEM). Cell-containing filters were fixed with $2.5 \%$ glutaraldehyde $(0.1 \mathrm{M}$ cacodylate buffer, $\mathrm{pH}$ 7.2), washed with PBS and post-fixed in $1 \% \mathrm{OsO}_{4}$ for $30 \mathrm{~min}$ in the dark at room temperature. After washing, the cells were dehydrated using increasing ethanol concentrations. Filter membranes were $\mathrm{CO}_{2}$ critical point dehydrated, metalized and observed using a JEOL JSM-6360 LV SEM.

Cultured B16F10 cells were analyzed by flow cytometry for cadherin, CD74 and 7-Amino-actinomycin D (7AAD) as viability markers and propidium iodide (PI) as a cell cycle marker. Log-phase growing B16F10 cultures were harvested by trypsin digestion, washed twice and re-suspended in PBS containing 1\% FBS. The harvested cells $\left(10^{6}\right)$ were incubated with anti-CD74/FITC (BD Pharmingen, San Diego, CA, USA) in PBS containing $1 \%$ FBS for $30 \mathrm{~min}$ and washed three times with PBS. For intracellular CD74 and cadherin, a simultaneous incubation was performed with anti-CD74/FITC (BD Pharmingen) and anti-cadherin/FITC (Vector Labs, Burlingame, CA, USA) antibodies using $0.01 \%$ saponin in the incubation buffer. Cells were also stained with 7-AAD (BD Pharmingen) for $5 \mathrm{~min}$ to estimate the number of dead cells. Cell cycle was determined as previously described [20]. Log-phase growing B16F10 cultures were detached by trypsin treatment, washed twice with PBS and fixed in chilled 70\% ethanol. After centrifugation, the fixed cell pellet was treated with RNAse at a concentration of $50 \mu \mathrm{g} / \mathrm{mL}$ (Sigma-Aldrich Chemical Co., St. Louis, MO, USA) and stained with $50 \mu \mathrm{g} / \mathrm{mL}$ propidium iodide (Sigma-Aldrich) for $10 \mathrm{~min}$ at room temperature. For all flow cytometry experiments, ten thousand events were acquired on a FACSCalibur using the CellQuest software (Becton-Dickinson), and data were analyzed using WinMDI 2.9 software.

\section{B16F10 lung metastasis and in vivo treatment}

B16F10 melanoma cells from a 70-80\% confluent monolayer culture were trypsinized, washed and suspended in DMEM. $1 \times 10^{5}$ cells were then resuspended in $0.1 \mathrm{~mL}$ of serum free DMEM and injected intravenously through the tail vein of $\mathrm{C} 57 \mathrm{BL} / 6$ mice for the development of lung metastasis. The treatment was started 24 hr after tumor cell inoculation. Animals ( $\mathrm{n}=9$ animals per group) were treated with inhalation of M8 or vehicle twice a day (12-12 hr) for 14 days, or were part of the 
control group that was not subjected to any treatment. The inhalation chamber was similar to the design previously described [21]. It nebulizes aqueous compounds for in vivo treatment of small rodents, aiming to directly distribute compounds to the lung, the specific pathologic site. The chamber was mounted in a plastic box that was coupled to a micropump nebulizer (Inalar - NS, Brazil), which was situated at the inlet of the chamber. M8 or its vehicle was nebulized through the inlet into the chamber (Figure 1). Air was circulated from the chamber outlet through small pores in the box. Following a dose of $10 \mathrm{~mL} / 5 \mathrm{mice} / 10 \mathrm{~min}$, the mice were removed from the chamber and allowed to equilibrate for $15 \mathrm{~min}$ and then replaced in the animal facility until the next dose was administered. After treatment, animals were subjected to euthanasia by an intraperitoneal injection of thiopental, followed by decapitation. Blood from each animal was collected in disodium EDTA vacutainers (BD, San Jose, CA, USA) and was used for immunophenotyping assays. Lungs were chirurgic acquired, placed in Petri dishes with PBS and rapidly analyzed (before histological fixation) with a stereomicroscope for the presence of black metastatic nodules.

\section{Blood leukocytes and bone marrow cell analysis}

For immunophenotyping analyses, blood aliquots containing $10^{6}$ leucokytes were incubated for $10 \mathrm{~min}$ with PharM Lyse (BD) for red blood cells lysis, followed by an 30 min incubation with anti-CD3/FITC, anti-CD4/ $\mathrm{PE}$, anti-CD8/PE, anti-CD11b, anti-CD16/32 (Fc block), anti-CD19/PE, anti-CD45 and anti-Pan-NK/PE. All antibodies were monoclonal antibodies (MAbs) from BD Pharmingen and were diluted in PBS with 1\% FBS. After the MAbs binding, cells were washed three times with
PBS and analyzed by flow cytometry using a FACSClibur (BD). For each sample, ten thousand events were acquired using the CellQuest software (BD) and data analysis was performed using WinMDI 2.9 software. FITC and PE isotype controls (BD Pharmingen) were used to calibrate the cytometer before the experimental sample acquisition. For bone marrow cells, the protocol was performed as previously described [14]. Briefly, femurs were dissected and cleaned. Epiphyses were removed and the marrow was flushed with DMEM (GIBCO). Cells $\left(10^{6}\right)$ were fixed with $1 \%$ paraformaldehyde, washed, and incubated for $40 \mathrm{~min}$ with biotinylated antibodies from a Mouse Lineage Panel Kit (BD, Pharmingen): anti-CD3, anti-B220, anti-Ly6G, antiTER119, anti-CD11b, anti-CD11c. Samples were then washed with PBS and incubated with $0.5 \mu \mathrm{g} / \mathrm{mL}$ of streptavidin-PE (BD, Pharmingen) in PBS for $30 \mathrm{~min}$ and subsequently, cells were acquired and analyzed for blood samples as described. Blood aliquots were also stained with May-Gründ-Giemsa (InstantProv Kit, NewProv, Brazil), allowing for differential counting of basophils, neutrophils, eosinophils and monocytes by light microscopy.

\section{Lung histopathology, immunohistochemistry, and ultrastructural pathology}

After blood sampling, lungs were dissected, washed once with PBS and fixed by immersion in $4 \%$ paraformaldehyde in PBS for $1 \mathrm{hr}$. After washing with PBS, lungs were dehydrated using increasing ethanol concentrations, xylene and embedded in paraffin. For histopathology analysis, $5 \mu \mathrm{m}$ sections of lungs were deposited on silane coated slides. Sections were deparaffinized in xylene, hydrated in alcohol, and incubated in $3 \% \mathrm{H}_{2} \mathrm{O}_{2}$

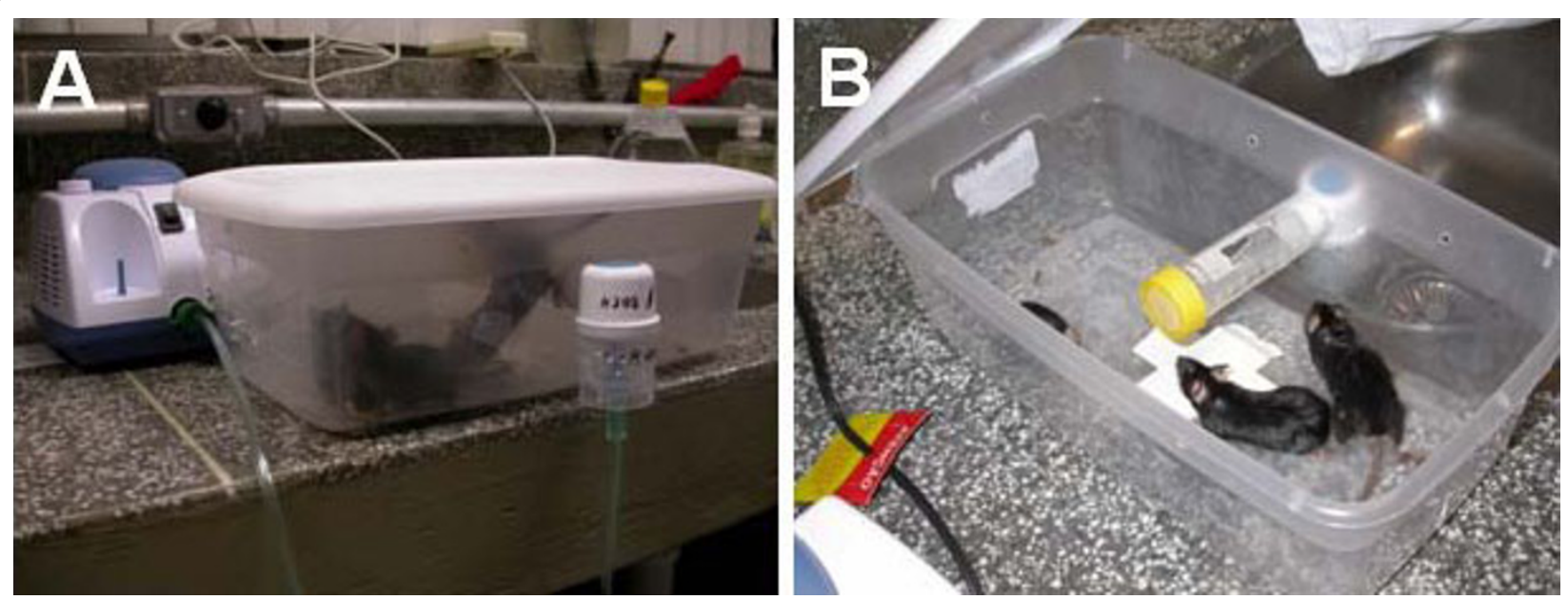

Figure 1 Inhalation chamber designed to nebulize aqueous compounds for in vivo treatment of small rodents, directly distribution compounds to the lung, the specific pathologic site. The chamber was mounted in a plastic box that was coupled into a micropump nebulizer that was situated at the inlet of the chamber (A), and M8 was nebulized through the inlet into the chamber (B). 
in methanol to block endogenous peroxidase activity. A Retrievagen A ( $\mathrm{pH}$ 6.0) kit (BD Pharmingen) was used for antigen unmasking, nonspecific binding was blocked by $1 \%$ BSA-PBS solution and possible aldehyde groups were blocked by $50 \mathrm{mM}$ glycine-PBS. Anti-CD11c, antiGR-1 (BD) and anti-perlecan proteoglycan (Affinity Bioreagents), as well as the isotype controls (BD Pharmingen), were diluted 1:50 in 0.1\% BSA/PBS and incubated on slides in a humidified chamber for $2 \mathrm{hr}$. After washing with PBS, the respective secondary biotinylated antibody (BD Pharmingen) was added at the same dilution and incubated for $1 \mathrm{hr}$ more, then washed, followed by an incubation step with streptavidin-HSP (BD Pharmingen) for $1 \mathrm{hr}$. After washing with PBS, MAbs binding was revealed with a DAB Substrate kit (BD Pharmingen). Slides were stained with Giemsa (EMS) and rapidly dehydrated in ethanol, xylene and then coverslips were mounted with entellan. Sections were scanned with a Nikon Eclipse E200 microscope and the areas of the highest immunostaining were imaged at $(12.5 \times 100) \times$ magnification. CD11c and GR-1 positive spots were counted in 10 chosen fields with highest density. Perlecan expression in tumor zones was quantified by color area measurement by Image software (NIH) to distinguish DAB stain from melanin, which turns color from brown to dark green after Giemsa stain [22]. For conventional histopathology analysis, a periodic acid-Schiff (PAS) stain was performed on the same samples and sections were scanned by a microscope at $(12.5 \times 40) \times$ or $100 \times$ magnification.

For transmission electron microscopy, a rapid protocol was performed as previously described [23]. Briefly, small pieces of lung tissue $\left(1 \mathrm{~mm}^{3}\right)$ containing melanoma nodules were fixed for 20-30 min with Karnovsky's fixative (2\% glutaraldehyde, $4 \%$ paraformaldehyde, $5 \mathrm{mM} \mathrm{CaCl}_{2}$, in $0.1 \mathrm{M}$ cacodylate buffer, $\mathrm{pH} 7.2$ - 7.4); they were then washed with the same buffer and post-fixed with $1 \%$ osmium tetroxide, $1 \mathrm{mM}$ $\mathrm{CaCl}_{2}, 0.8 \%$ potassium ferricyanide in $0.1 \mathrm{M}$ cacodylate buffer ( $\mathrm{pH} 7.4$ ) for 15 minutes and then rinsed twice for $1 \mathrm{~min}$ with the same buffer. The lung pieces were dehydrated with acetone $50 \%, 70 \%, 90 \%$ and $100 \%(2 \times)$ for 3 minutes each. The tissues were transferred to bean capsules containing $90 \%$ acetone and infiltrated in epoxy resin (Epon)/acetone solution (1:1) for $2 \mathrm{hr}$, then in pure Epon for $4 \mathrm{hr}$ and, lastly, embedded in a new Epon solution overnight. Polymerization was carried out for $48 \mathrm{hr}$ at $60^{\circ} \mathrm{C}$. Ultra-thin sections were stained with aqueous uranyl acetate for $15 \mathrm{~min}$ and with lead citrate for $2 \mathrm{~min}$. Samples were visualized with a Jeol JEM 1011 transmission electron microscope. A GATAN CCD camera and GATAN digital micrograph software were used to obtain the digital images.

\section{Micrographs and statistics analysis}

Micrographs obtained from immunohistochemistry and electron microscopy were analyzed by ImageJ software $(\mathrm{NIH})$ to obtain mean/pixel values from the specific threshold of transwell insert pores or IHC chromogen. Data obtained from assays were transformed to conform to a normal distribution using the equation transformed data $=\sqrt{x+0.5}$. Statistical significance of transformed data was determined using a one-way analysis of variance (ANOVA), followed by Tukey post test. Statistical significance is presented as either $\mathrm{P}<0.05\left(^{*}\right)$ or $\mathrm{P}<$ $\left.0.01{ }^{* * *}\right)$. Data are representative of three independent experiments performed in triplicate.

\section{Results}

\section{$\mathrm{M} 8$ in vitro effects on B16F10 cells}

First, we wanted to address the in vitro effect of $M 8$ treatment on B16F10 cells. After 48 h exposure, viability, cell cycle, protein expression associated with tumor process and adhesion/invasion in matrigel were analyzed. Cell viability, assessed by 7-AAD stain, did not show significant differences between control, vehicle and M8 (data not shown). Cell cycle was evaluated and there was a clear trend toward a decrease in the number of cells in S and G2 phases; however, the data did not reach statistical significance $(p=0.08)$ (data not shown). Flow cytometry analysis of the expression pattern of some key proteins linked with the tumoral process showed no differences in the intracellular expression of E-cadherin or intracellular/extracellular expression of CD74 (data not shown). However, when the effect of M8 treatment in adhesion and invasion in matrigel was assessed, a promising result was observed. Electron microscopy analysis of the invasion assay on fibronectin/matrigel coated in transwell inserts with $8 \mu \mathrm{m}$ pores showed a decrease in B16F10 cell adhesion in matrigel that was associated with a decrease in matrigel degradation after M8 treatment (Figure 2). ImageJ analysis of the pores clearly shows a loss of adhesion of B16F10 cells, accompanied by a decrease in the number of cells on the matrigel subtract. When cells were treated with M8, there was more non-degraded matrigel obstructing the pores, leading to a diminished number of exposed pores. These data suggest that M8 decreases cellular invasion.

\section{In vivo evaluation of $\mathrm{M} 8$ treatment in lung metastasis}

Taking into account the promising results obtained in vitro, the next step was to evaluate the in vivo effect of M8 in a lung metastasis model. C57BL/6 mice were injected intravenously with B16F10 cells to develop lung metastasis. The treatment was started $24 \mathrm{hr}$ after tumor cell inoculation and the animals were treated with M8 or vehicle twice a day for 14 days. A decrease in the 


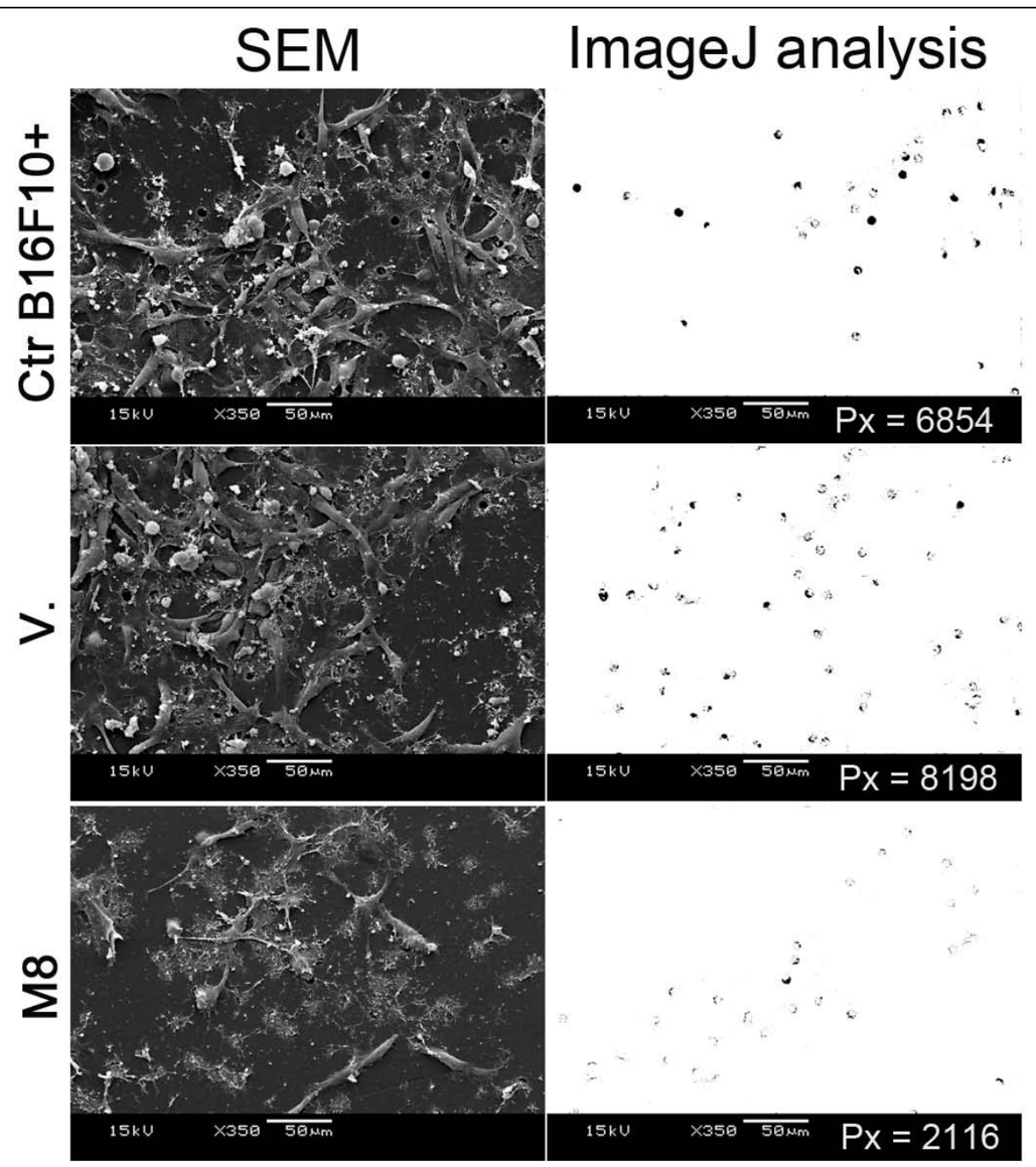

Figure 2 In vitro treatment of B16F10 cells. Untreated cells (Ctr. B16F10+), vehicle treated cells (V) and M8 treated cells (M8), respectively. Scanning electron micrographs (SEM) of invasion assay on fibronectin/matrigel-coated transwell inserts with $8 \mu \mathrm{m}$ pores. Original micrographs were analyzed by ImageJ software and the total area of $8 \mu \mathrm{m}$ pores was evaluated in pixels (Px). Black density of pores is directly proportional to matrigel wall degradation by B16F10 cells. ImageJ analysis of pores shows the loss of adhesion of B16F10 cells, accompanied by a decrease in cell number on the matrigel substrate, as well as the permanence of non-degraded matrigel obstructing the pores in the cells treated with $M 8$, diminishing the number of exposed pores.

number of tumoral nodules was observed in lungs after M8 treatment (Figure 3A-D). This observation was confirmed by the statistical analysis of the number of tumor nodules, which showed that the difference between the control and the M8-treated mice was significant $(* * \cdots \mathrm{P}<$ 0.001) (Figure 3E).

Histopathology analysis showed a difference in tumor nodule pattern distribution, concentration and area in lung histology sections. From a structural point of view, it was observed that melanoma cells with poliedric morphology with a great amount of melanin content as cytoplasm granules or in a perinuclear distribution. Additionally, aberrant nodular proliferation in bronchoalveolar regions, characteristic of epithelial melanoma, was observed (Figure 4B and 4C, respectively). After M8 treatment (Figure 4D), tumor nodules were decreased and organized in a predominantly peripheral distribution, whereas, in control and vehicle groups, the nodules were larger and distributed in the lung parenchyma.

An ultrastructural overview by transmission electron microscopy showed a characteristic pulmonary parenchyma (Figure 5), in which the presence of tumor cells with large amounts of very dense and black cytoplasmic pigment granules (melanosomes) is obvious. Surrounding these cells are many dying parenchyma cells with pyknotic nucleus (Figure 5A and 5B), characteristic of apoptotic cells. Figure $5 \mathrm{C}$ shows a tumor 

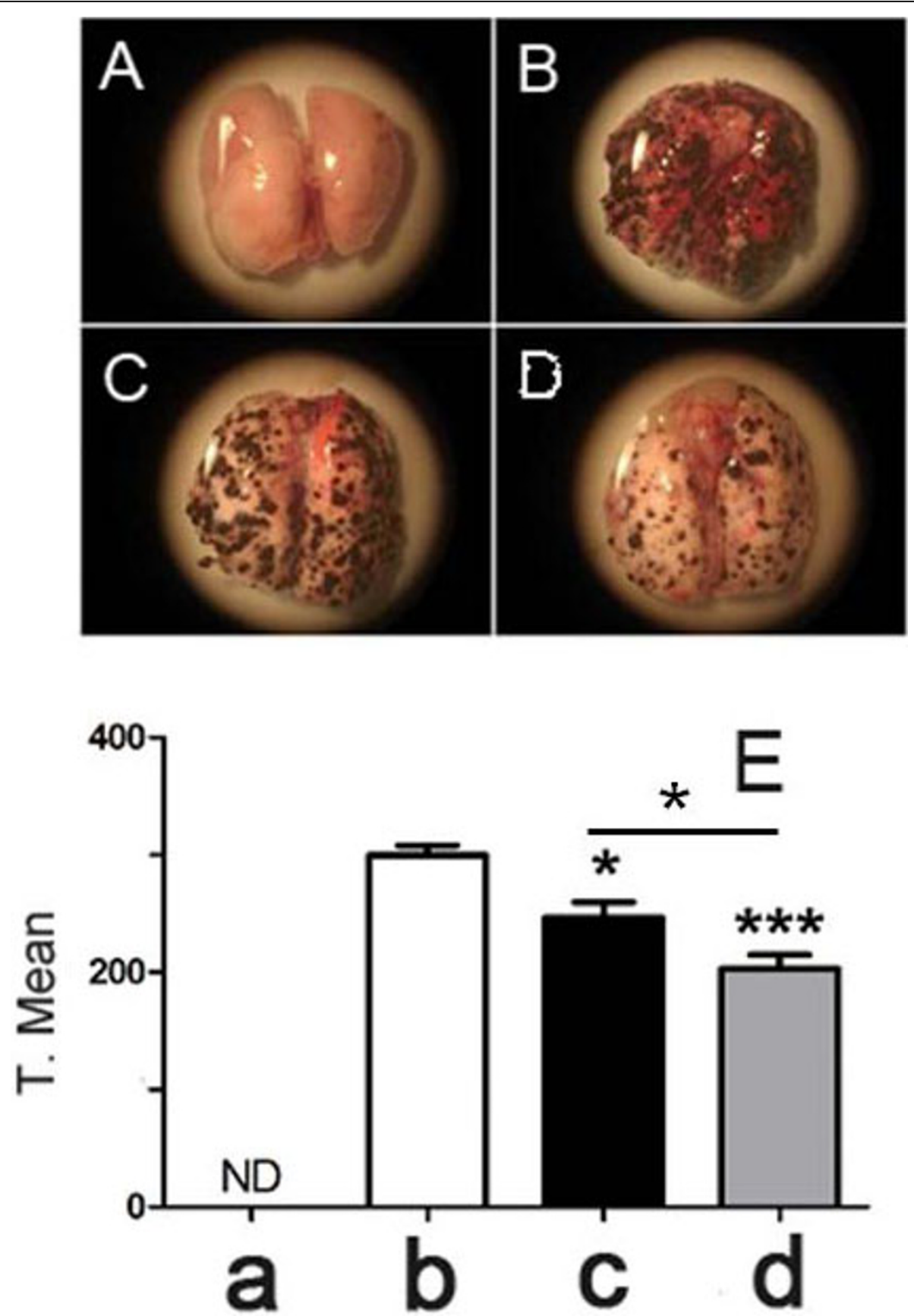

Figure 3 Lung metastasis in C57BL/6 mice induced from B16F10 tail vein injection. Figure A: Normal lung. Figure B, C and D: A mouse with B16F10 lung metastasis, untreated, vehicle treated or M8 treated, respectively. Figure $\mathbf{E}: \mathbf{a}=$ normal lung; $\mathbf{b}=$ untreated lung with B16F10 metastasis; $\mathbf{c}=$ lung with B16F10 metastasis treated with vehicle; $\mathbf{d}=$ lung with B16F10 metastasis treated with M8. Treatment caused a statistically significant decrease in metastasis $(* * * 00.001)$ and significantly decreased metastasis as compared with vehicle-treated animals (*P $<0.05)$. Y axis of graph $=$ transformed mean after normal distribution using the equation to transform data, $\sqrt{x+0.5}$.

cell at higher magnification, characterized by melanosome granules and increased metabolic activity, evidenced by a euchromatic nucleus and many mitochondria. Figure 5D shows a macrophage with internalized melanosomes, evidence of the phagocytosis of tumor cell products.

\section{Peripheral blood and bone marrow cell subpopulation} analysis after M8 treatment of mice with lung metastasis In order to determine whether the melanoma regression was mediated by immune cells, different subpopulations were quantified from blood and bone marrow derived from mice with lung metastasis. Blood leukocytes 

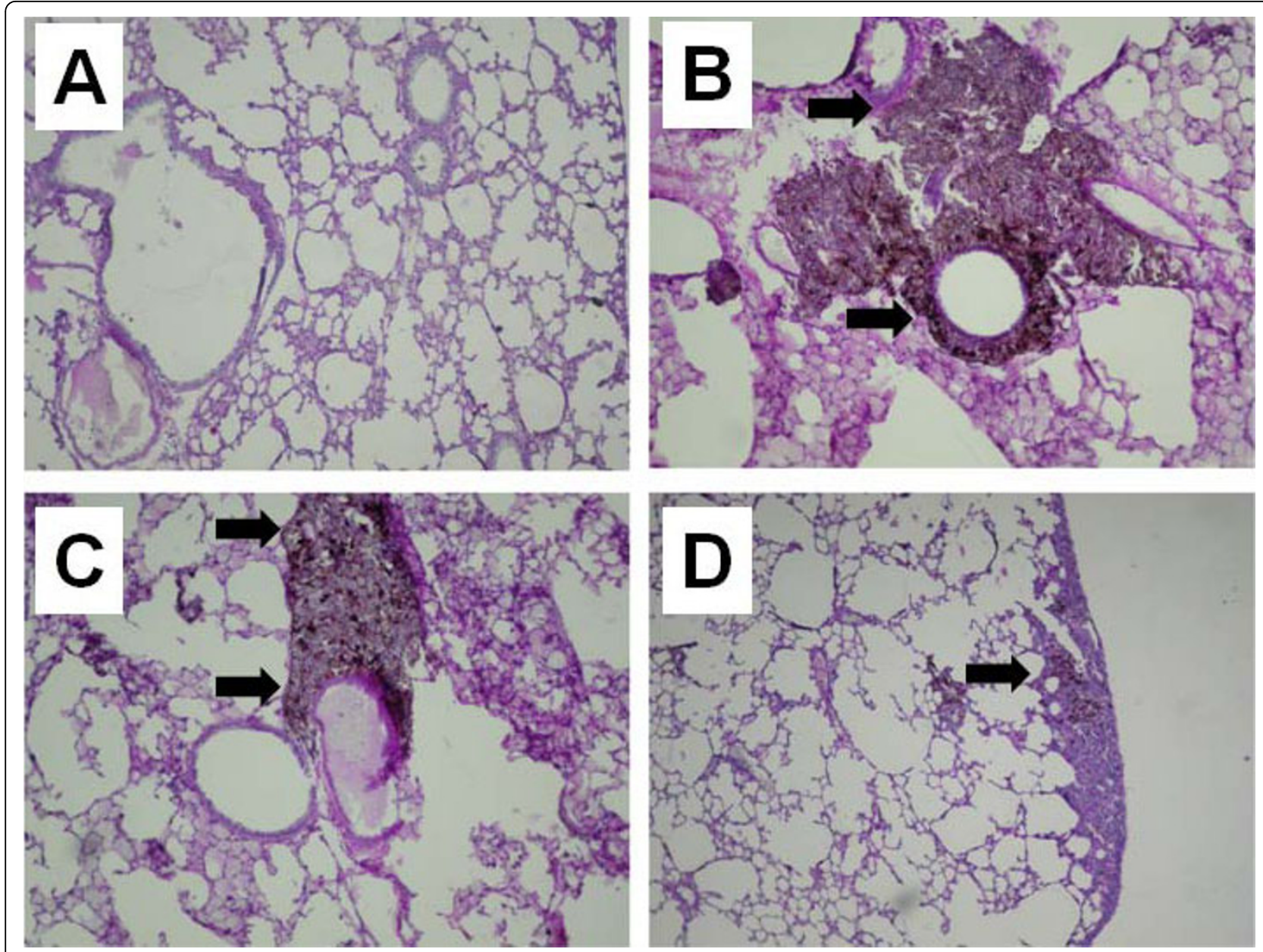

Figure 4 Histopathology analysis of normal lung (A), lung metastasis from untreated mice, control (B), lung metastasis from mice treated with the vehicle (C) and lung metastasis from mice treated with $\mathbf{M 8}$ (D). A significant difference was observed in tumor nodule pattern distribution, concentration and area. After M8 treatment (D), tumor nodules (arrows) were smaller and organized in a predominantly peripheral distribution, whereas in the control and vehicle groups the nodules were larger and distributed in the lung parenchyma (B and $C$, respectively).

analysis from M8 treated mice showed a significant increase in basophils and neutrophils concentrations, but not in eosinophils or monocytes (Figure 6). After lymphocyte immunophenotyping analyses, no significant differences were found in $\mathrm{B}\left(\mathrm{CD} 3^{-} \mathrm{CD} 19^{+}\right)$, NK $\left(\mathrm{CD}^{-}\right.$ Dx $\left.5^{+}\right)$, NKT $\left(\mathrm{CD}^{+} \mathrm{Dx} 5^{+}\right)$, Tc $\left(\mathrm{CD} 8^{+}\right)$, or Th $\left(\mathrm{CD} 4^{+}\right)$ lymphocytes in circulating blood (Figure 6). On the other hand, cells from bone marrow showed differences in the concentration of CD3 and CD11c positive cells, but not in the concentration of B220, CD11b, Ly6G and TER119 positive cells (Figure 7).

\section{Lung immunohistopathology}

The next step was to evaluate whether M8 treatment could affect lung-infiltrated or resident granulocytes and macrophages/dendritic cells. The concentration of those cell populations were estimated by cell counting on immunohistochemistry slides. Although the number of blood granulocytes (basophils and neutrophils) was increased after treatment, no significant differences were found in lung peritumoral granulocyte $\left(\mathrm{GR}-1^{+}\right)$or macrophages/dendritic cell $\left(\mathrm{CD} 11 \mathrm{c}^{+}\right)$number (Figure 8 ). Lung samples were also analyzed by immunohistochemistry for perlecan expression, a heparan sulfate proteoglycan. After M8 treatment, perlecan expression was significantly down regulated in tumor nodules (Figure 9A-D). This difference was more evident after quantification by ImageJ (Figure 9E).

\section{Discussion}

Tumor cells use multiple mechanisms to escape detection and elimination by the immune system, prompting the development of chemotherapeutic drugs that harness both humoral and cellular immunity to target 


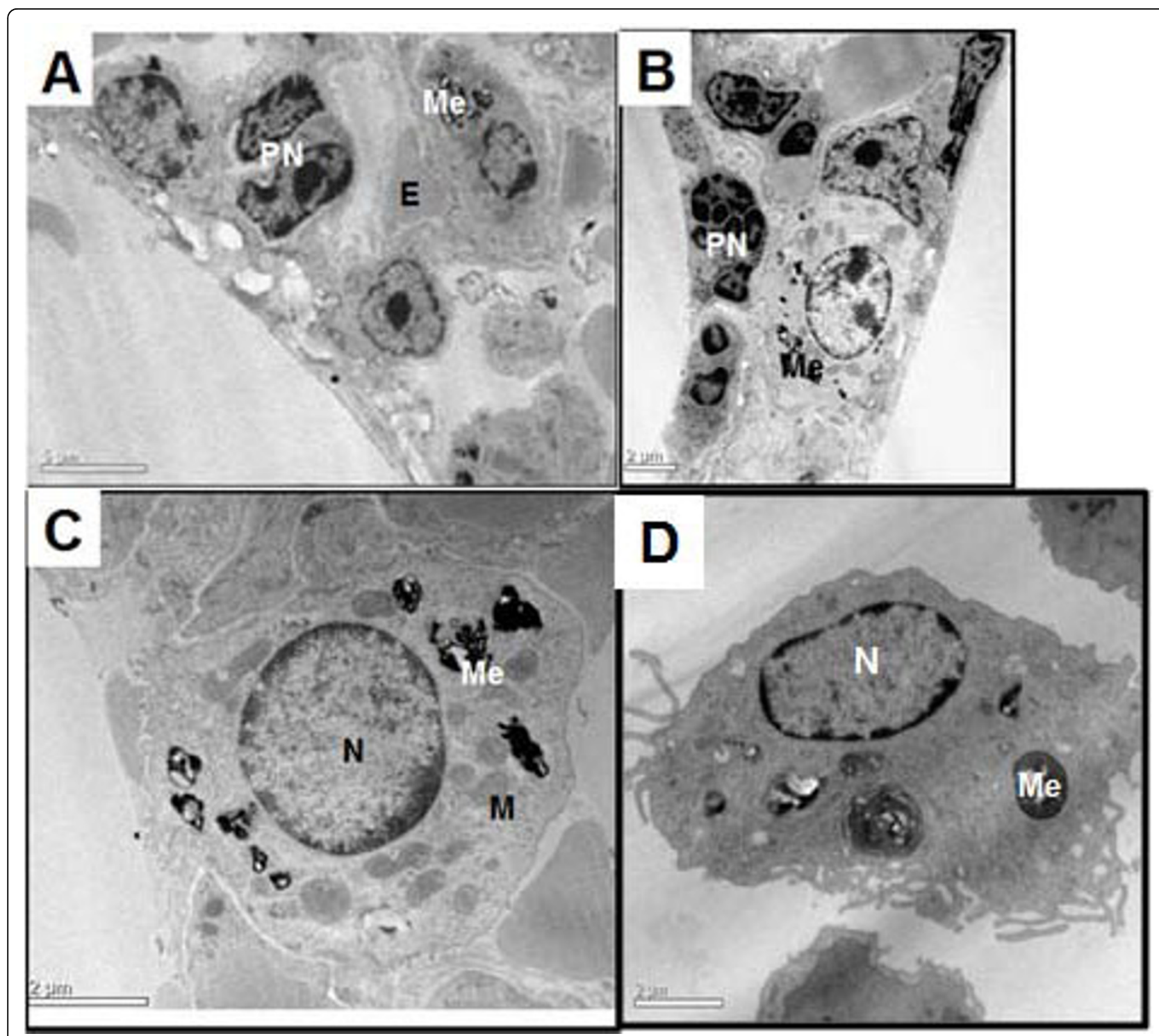

Figure 5 Ultrastructural overview by Transmission Electron Microscopy - Images of lungs with melanoma nodules. A: Lung cells in panoramic view, with nucleus (N), erythrocytes (E), pyknotic nucleus (PN), melanosomes (Me); B: Lung in a panoramic view with an evident tumor cell containing a big nucleus, melanosomes (Me) and many mitochondria; C: more details of a tumor cell, including the morphologic characteristics of intense metabolism, a big euchromatic nucleus, many mitochondria (Mi) and melanosomes. D: an alveolar macrophage with an euchromatic nucleus (N); many organelles, such as the endoplasmic reticulum and mitochondria, endocytic vacuoles, and internalized melanosomes (Me); and a surface covered with many cellular projections.

malignant cells. There is little basic research on the effectiveness of alternative and complementary therapies in cancer, and the few studies that have been performed were limited in scope. Beside this, immunostimulation by natural products has been attempted in various animal models and in human cancer patients as an adjunct to chemotherapy [24-26].

A high diluted complex treatment in macrophages has been shown to suppress previously elevated levels of tumor necrosis factor- $\alpha$ (TNF- $\alpha$ ), increase the activity of NADPH oxidase and the expression of inducible nitric oxide synthase (iNOS), and induce differential gene expression [9-11]. Many studies have demonstrated the role of different high diluted complexes in cancer therapy immunomodulation [13,17,27,28]. Regarding M8 (Calcarea carbonica and associations), our previous results showed that in vitro treatment significantly increased macrophages/lymphocyte interaction and effectiveness against melanoma cells [17]. Extending these previous data to the in vivo immunotherapeutic effect of this compound, we now demonstrate that M8 therapy prevents tumor growth and metastasis. 


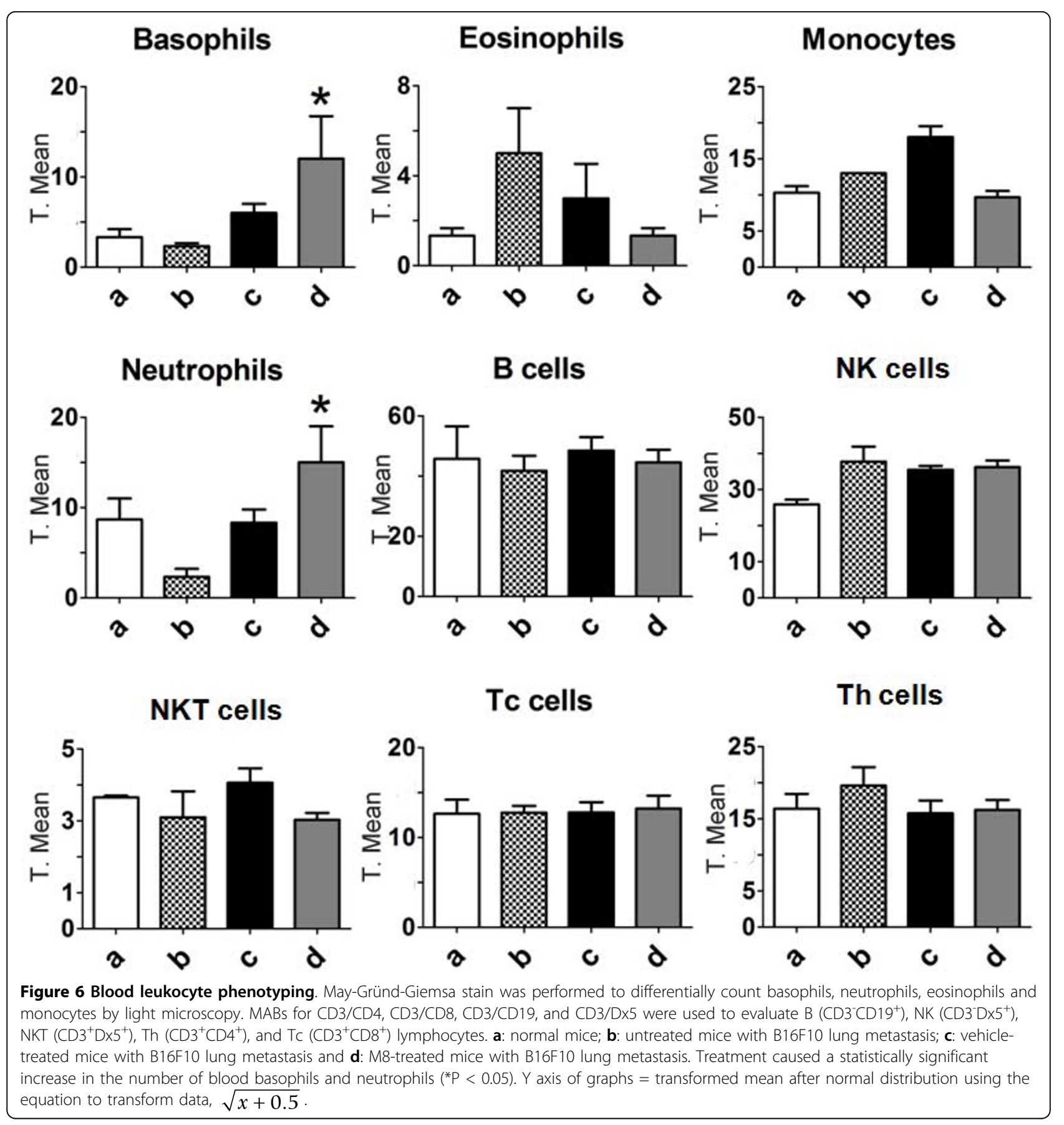

Progression of melanoma and other malignant cancers involves cellular changes such as the loss of Ecadherin expression and the gain of CD74 expression, which confer cell motility and immunologic escape, respectively $[29,30]$. However, while both molecules were analyzed in the present study, no differences were found after M8 treatment (data not shown). Despite this finding, scanning electron micrographs analysis clearly showed the loss of adhesion of B16F10 cells, demonstrated by a decreased cell number on the matrigel subtract, and the permanence of nondegraded matrigel obstructing the pores in the cells treated with $M 8$, leading to a diminished number of exposed pores (Figure 2).

Since interferon type I based immunostimulation has been studied as an effective immunotherapy for melanoma cases [31], we further investigated the in vitro effect of M8 on type I IFN activity using 

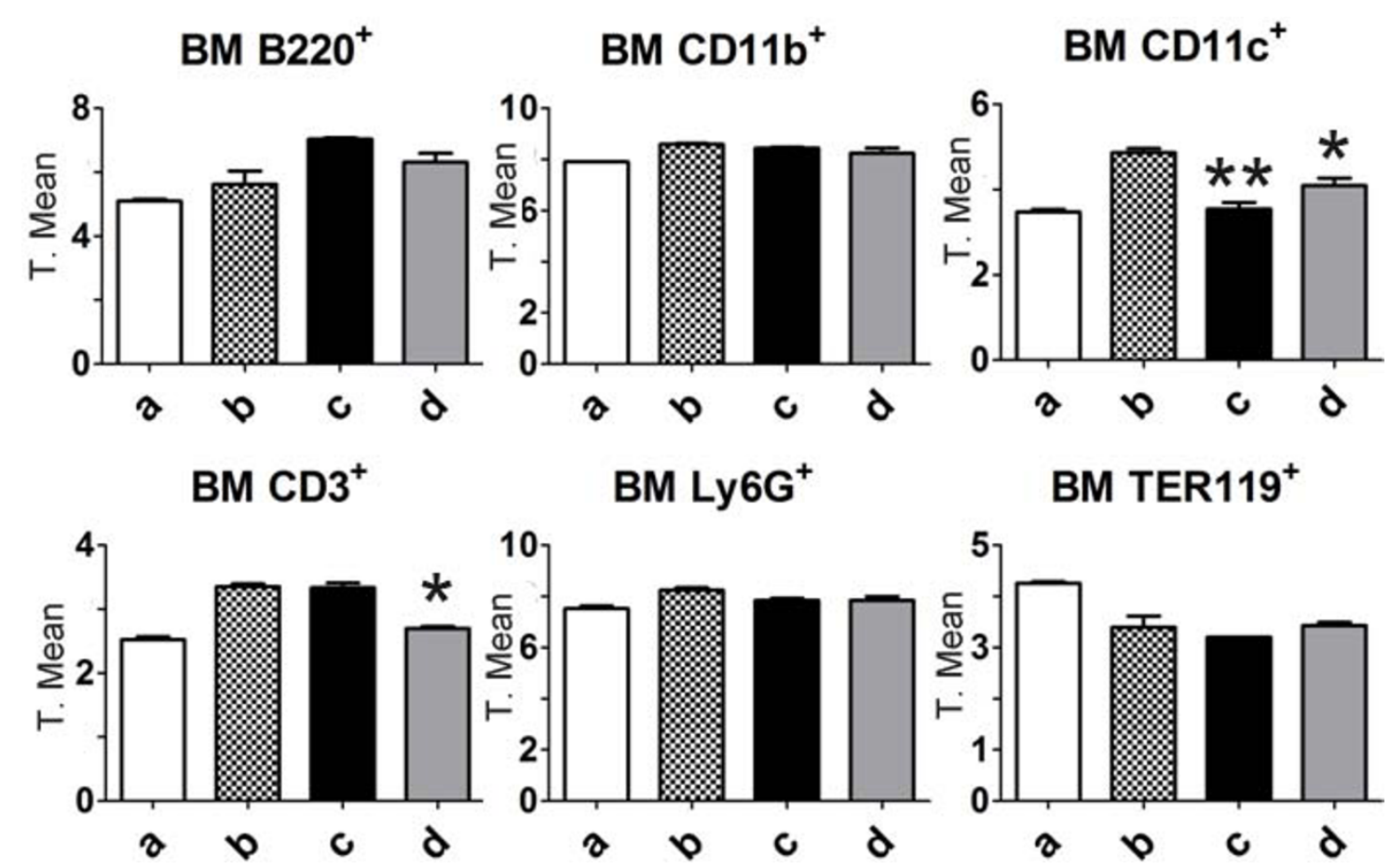

Figure 7 Bone marrow cell phenotyping. MABs for CD3, CD11b, CD11c, B220, Ly6G and TER119 were used to evaluate T precursor cells $\left(\mathrm{CD}^{+}\right)$, monocyte precursors $\left(\mathrm{CD} 11 \mathrm{~b}^{+}\right)$, dendritic cell precursors $\left(\mathrm{CD} 11 \mathrm{C}^{+}\right)$, granulocyte precursors $\left(\mathrm{Ly}_{6} \mathrm{G}^{+}\right)$and erythrocyte precursors (TER119). a: normal mice; b: untreated mice with B16F10 lung metastasis; c: vehicle-treated mice with B16F10 lung metastasis and d: M8-treated mice with B16F10 lung metastasis. Most markers showed a normalization tendency, i.e. the values from treated mice were similar to the values from normal mice. $Y$ axis of graphs $=$ transformed mean after normal distribution using the equation, to transform data, $\sqrt{x+0.5}$.

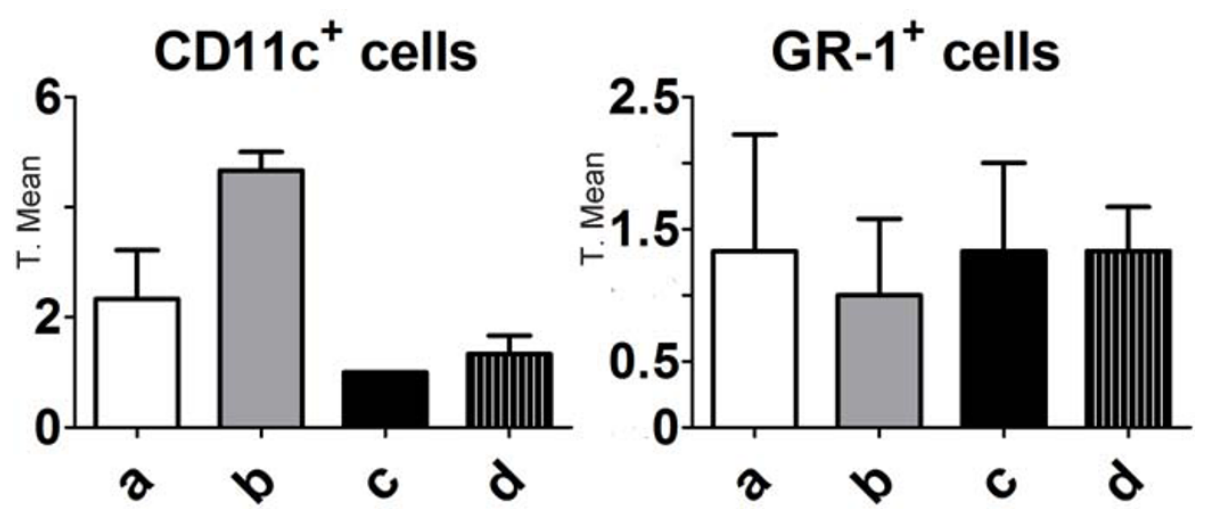

Figure 8 Immunohistochemistry quantification of CD11c (monocytic/dendritic cell marker) and GR-1 (granulocytic marker) cells. a: normal mice; b: untreated mice with B16F10 lung metastasis; c: vehicle-treated mice with B16F10 lung metastasis and $\mathbf{d}$ : M8-treated with B16F10 lung metastasis. No statistically significant differences were found after developing with HSP/TMB (blue) and counting positive cells. $\mathrm{Y}$ axis of graph $=$ transformed mean after normal distribution using the equation to transform data, $\sqrt{x+0.5}$.

MxRage reporter cells [18]. When these cells were exposed to M8, no agonist or antagonism capacity was observed (Additional file 1: Supplementary Figure A). Moreover, NF- $\kappa \mathrm{B}$ has been reported to increase tumourigenesis by promoting anti-apoptotic activity, chemotherapy resistance, the expression of positive cell cycle regulators and the expression of other survival factors [32]. However, no agonistic or antagonistic NF- $\kappa$ B activation was found after M8 treatment in the HT29 reporter model (Additional file 1: Supplementary Figure B).

On the other hand, lung metastasis regression was observed in vivo after M8 treatment (Figure 3 and 4). In order to evaluate the mechanism of action of M8 

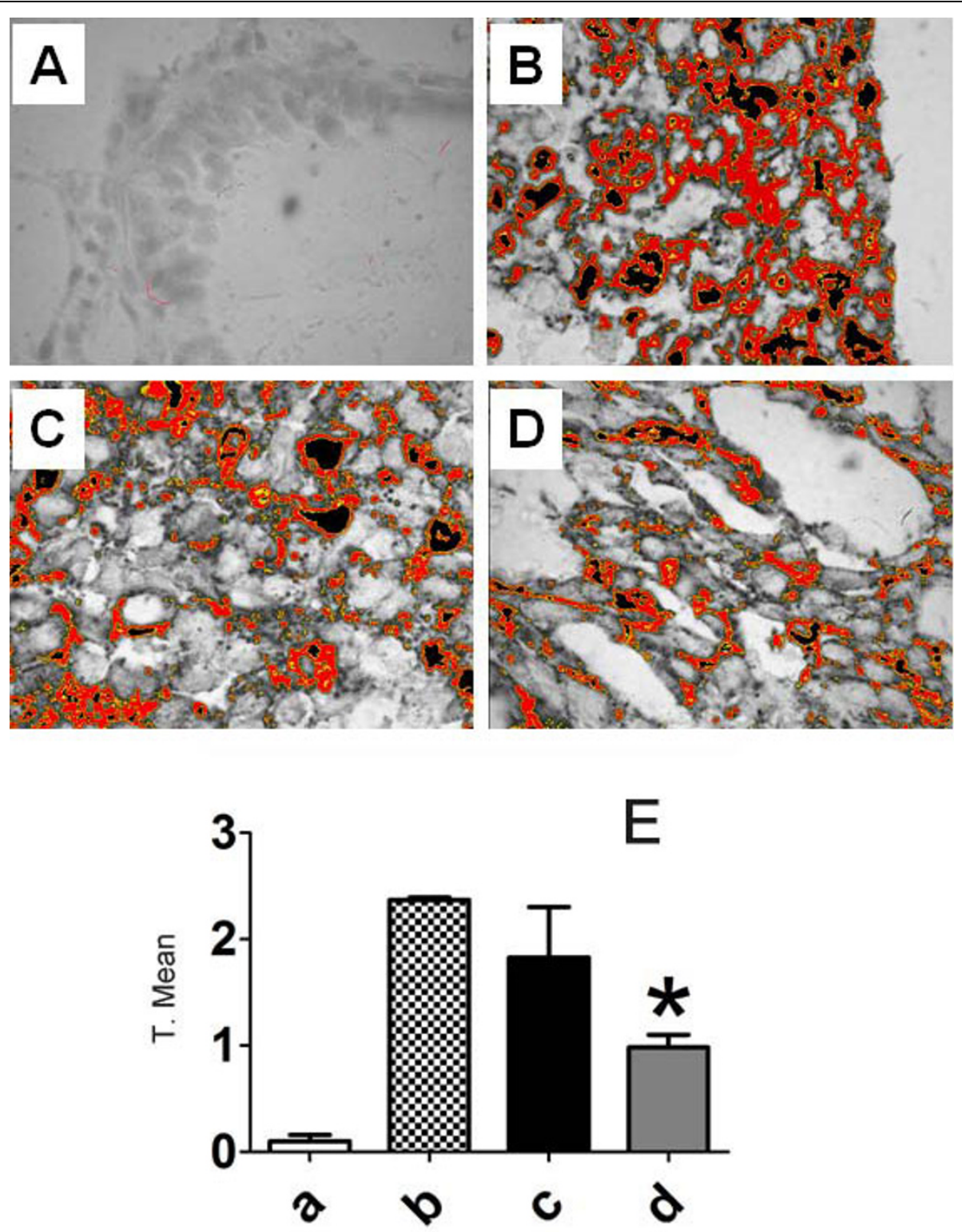

Figure 9 Perlecan quantification in metastatic nodules by immunohistochemistry. Staining melanocytic samples with Giemsa results in a uniform dark green/blue coloration of melanin that is easily distinguishable from the DAB precipitate of the HSP reaction. DAB-specific threshold selection from selected tumor areas was performed by ImageJ software (red/orange selection in Figures A, B, C and D), and total selected area was quantified and statistically analyzed (E). a: normal mice; $\mathbf{b}$ : untreated mice with B16F10 lung metastasis; $\mathbf{c}$ : vehicle-treated mice with B16F10 lung metastasis and $\mathbf{d}$ : M8-treated mice with B16F10 lung metastasis. M8 treatment resulted in a statistically significant decrease in heparan sulfate proteoglycan expression. $\mathbf{A}=$ Normal lung; $\mathbf{B}=$ B16F10 positive control; $\mathbf{C}=$ Vehicle treatment; $\mathbf{D}=$ M8 treatment. $\mathrm{Y}$ axis of graphs $=$ transformed mean after normal distribution using the equation to transform data, $\sqrt{x+0.5}$.

in vivo, the level of immune cells was analyzed. Previous studies have shown that this category of medicament increases blood lymphocytes such as TCD4, TCD 8 and NK, which are associated with tumor regression in an albino Swiss mice/Sar-180 model [13]. In a C57BL/6 mice/B16F10 model, there was no significant difference in lymphocyte level from blood and bone marrow (Figure 6 and 7). However, the difference between the results obtained with the C57BL/6 strain and albino Swiss strain may be because the first mouse model has an intrinsic and well established innate and Th1 response that limits its use immunological questions [33]. On the other hand, it is the most used murine model to simulate metastatic melanoma because it 
reflects several characteristics of human metastatic melanoma, and because B16F10 cell inoculation is only compatible with this strain [34]. An increase in the number of circulating basophils and neutrophils was observed after M8 treatment. Basophils and neutrophils have been recently appointed as promissory innate cells to be targeted for anti-cancer treatment because are the first cells able to detect tissue abnormalities as tumor necrosis or growth damages tissue [35]. There was no significant difference in bone marrow leukocytes number, but there was a clear tendency for CD4 and CD11c markers (Figure 7) to be close to the levels seen in normal mice, demonstrating a "normalization" of bone marrow cell production.

This study provides some information to clarify the mechanism by which M8 treatment affects melanoma metastasis in this model. We observed a decrease in perlecan expression and a direct inhibition of cancer cell adhesion and invasion (Figure 2 and 9). Perlecan is an important component of basement matrix and its expression correlates strongly with the expression of several metastatic, angiogenic and invasive factors in tumor cells, particularly melanoma cells. Tumorderived perlecan is distributed throughout its matrix and creates a microenvironment that favors neovascularization, tumor growth and invasion [36,37]. Perlecan has been identified as a potential therapeutic target for the treatment of metastatic cancer because it is a necessary molecule for tumor vessels' structural integrity and forms the major storage site of neovascularization factor FGF-2 [7,38]. Despite this, the inhibition of adhesion of extracellular matrix molecules in melanoma cells causes cell rounding, loss of survival and apoptosis [39]. This result is corroborated by the invasion assay, which showed a loss of adhesion of B16F10 cells to the Matrigel substrate because of a decrease in the ECM proteolysis ability of the cells (Figure 2).

\section{Conclusion}

Taken together, these results may explain the possible tumor cell dormancy and decrease in tumor nodule number and volume caused by M8 treatment. These findings suggest that M8 is a promising therapy that may improve the innate immune response against tumor cells, decreasing the cell adhesion or invasion of malignant cells or even inducing direct dormancy in malignancies. Further studies are necessary to clarify the precise and detailed mechanism of M8 treatment in anti-tumor effects in melanoma and its use as combination-therapy candidate used in addition with conventional medicines.
Additional file 1: In vitro type I IFN and NF- $\kappa$ B assays. In order to verify the possible influence of $M 8$ treatment in type I IFN and/or NF- $\kappa$ B signaling, a preliminary screening was performed. Quantitative examination of M8 treated Mx-RAGE and HT29 cells by flow cytometry showed no statistically significant differences in type I IFN and/or NF- $\kappa$ B activity, respectively (Supplementary Figures A and B, respectively). Supplementary Figure A: M8 in vitro treatment of MxRage cells, a reporter cell line to evaluate type I IFN activity. No significant differences were found in GFP expression during the screening. Both negative and positive circumstances were evaluated for the ability to increase IFN production (compound alone) and the ability to decrease IFN production (compound plus IFN- $\alpha$ ). GFP expression was evaluated by flow cytometry analysis of treated cells. No differences in cell viability were detected by 7-AAD stain. Supplementary Figure B: The HT29-pNF- $\kappa$ B-hrGFP reporter cell line was used to evaluate the activation of NF- $\kappa$ B after in vitro treatment with M8. No significant differences were found in NF- $\kappa \mathrm{B}$ activation after treatment. Both negative and positive scenarios were evaluated for the ability to activate NF- $\kappa \mathrm{B}$ (compound alone) and the ability to decrease NF- $\kappa$ B activation (compound plus TNF- $\alpha$ ). GFP expression was evaluated by flow cytometry of treated cells. No differences in cell viability were detected by 7-AAD stain. $Y$ axis of graphs $=$ transformed GFP mean after normal distribution using the equation to transform data, $\sqrt{x+0.5}$

\section{Acknowledgements}

We thank CNPq, Fundação Araucária, and SETI-PR for financial support. We are especially grateful to Centro de Microscopia Eletrônica at UFPR and Laboratório Central de Microscopia Eletrônica at UFSC, and to UATE at IPMon, Uruguay.

\section{Author details}

${ }^{1}$ Laboratório de Pesquisa em Células Inflamatórias e Neoplásicas Depto de Biologia Celular, Setor de Ciências Biológicas, Federal University of Paraná, Brazil. ${ }^{2}$ Cell Biology Unit (CBU), Institut Pasteur de Montevideo (IPMon), Uruguay.

\section{Authors' contributions}

FSFG designed and performed all experiments, analysis and drafted the manuscript. RS, IT and MBF collaborated on cell culture and in vitro assays. LAF, SHM, APRB and CW collaborated on cell culture and in vivo assays. DFB and EST designed and supervised all experiments and manuscript writing. All authors have read and approved the final manuscript.

\section{Competing interests}

The authors declare that they have no competing interests.

Received: 23 July 2009 Accepted: 25 March 2010

Published: 25 March 2010

\section{References}

1. Rigel DS, Carucci JA: Malignant melanoma: Prevention, early detection, and treatment in the $21^{\text {st }}$ Century. CA-Cancer J Clin 2000, 50:215-36.

2. Thompson JF, Scolyer RA, Kefford RF: Cutaneous melanoma. Lancet 2005, 365:687-701.

3. Smalley KS, Herlyn M: Integrating tumor-initiating cells into the paradigm for melanoma targeted therapy. Int J Cancer 2009, 124(6):1245-50.

4. Satzger I, Meier A, Schenck F, Kapp A, Hauschild A, Gutzmer R: Autoimmunity as a prognostic factor in melanoma patients treated with adjuvant low-dose interferon alpha. Int J Cancer 2007, 121:2562-2566.

5. Claffey KP, Brown LF, del Aguila LF, Tognazzi K, Yeo KT, Manseau EJ, Dvorak HF: Expression of vascular permeability factor/vascular endothelial growth factor by melanoma cells increases tumor growth, angiogenesis, and experimental metastasis. Cancer Res 1996, 56:172-181.

6. Sanderson RD, Yang Y, Kelly T, MacLeod V, Dai Y, Theus A: Enzymatic remodeling of heparan sulfate proteoglycans within the tumor 
microenvironment: Growth regulation and the prospect of new cancer therapies. J Cell Biochem 2005, 96:897-905.

7. Fjeldstad K, Kolset SO: Decreasing the metastatic potential in cancers targeting the heparan sulfate proteoglycans. Curr Drug Tar 2005, 6:665-82.

8. Bergman PJ: Cancer immunotherapy. Top Companion Anim Med 2009, 24:130-136.

9. Piemonte MR, Buchi DF: Analysis of IL-2, IFN-gamma and TNF-alpha production, alpha5 beta1 integrins and actin filaments distribution in peritoneal mouse macrophages treated with homeopathic medicament. J Submicr Cytol Pathol 2002, 34(3):255-263.

10. Oliveira CC, Oliveira SM, Godoy LM, Gabardo J, Buchi DF: Canova, a Brazilian medical formulation, alters oxidative metabolism of mice macrophages. J Infection 2006, 52:420-32.

11. Oliveira CC, Oliveira SM, Goes VM, Probst CM, Krieger MA, Buchi DF: Gene expression profiling of macrophages following mice treatment with an immunomodulator medication. J Cell Biochem 2008, 104:1364-77.

12. Seligmann IC, Lima PD, Cardoso PC, Khayat AS, Bahia MO, Buchi DF, Cabral IR, Burbano RR: The anticancer homeopathic composite "Canova Method" is not genotoxic for human lymphocytes in vitro. Genet Mol Res 2003, 2:223-228.

13. Sato DY, Wal R, Oliveira CC, Cattaneo RI, Malvezzi M, Gabardo J, Buchi DF: Histopathological and immunophenotyping studies on normal and sarcoma 180-bearing mice treated with a Brazilian homeopathic medication. Homeopathy 2005, 94(1):26-32.

14. Abud AP, Cesar B, Cavazzani LF, Oliveira CC, Gabardo J, Buchi DF: Activation of bone marrow cells treated with Canova in vitro. Cell Biol Int 2006, 30(10):808-816.

15. Cesar B, Abud APR, Oliveira CC, Cardoso F, Gremski W, Gabardo J, Buchi DF: Activation of mononuclear bone marrow cells treated in vitro with a complex homeopathic medication. Micron 2008, 39(4):461-470.

16. Cesar B, Abud APR, Oliveira CC, Cardoso F, Bernardi RP, Guimaraes FSF, Gabardo J, Buchi DF: Treatment with at homeopathic complex medication modulates mononuclear bone marrow cell differentiation. Evid Based Complement Alternat Med

17. Guimaraes FSF, Abud AP, Oliveira SM, Oliveira CC, César B, Donatti L, Gabardo J, Trindade ES, Buchi DF: Stimulation of lymphocyte antimelanoma activity by co-cultured macrophages activated by complex homeopathic medication. BMC Cancer 2009, 9:293.

18. Bollati-Fogolín M, Müller W: Virus free, cell-based assay for the quantification of murine type I interferons. J Immunol Methods 2005, 306:169-175

19. Zhao W, Liu H, Xu S, Entschladen F, Niggemann B, Zänker KS, Han R: Migration and metalloproteinases determine the invasive potential of mouse melanoma cells, but not melanin and telomerase. Cancer Lett 2001, 162:49-55.

20. Dua P, Gude RP: Antiproliferative and antiproteolytic activity of Pentoxifylline in cultures of B16F10 Melanoma cells. Cancer Chemother Pharmacol 2006, 58:195-202.

21. McConville JT, Willians RO, Carvalho TC, Iberg AN, Johnston KP, Talbert RL, Burgess D, Peters Jl: Design and evaluation of a restraint-free small animal inhalation dosing chamber. Drug Develop Ind Pharm 2005, 31:35-42.

22. Monteagudo C, Martin JM, Jorda E, Llombart-Bosch A: CXCR3 chemokine receptor immunoreactivity in primary cutaneous malignant melanoma: correlation with clinicopathological prognostic factors. J Clin Pathol 2007, 60:596-599.

23. Guimaraes FSF, Oliveira SM, Oliveira CC, Donatti L, Buchi DF: A shorter fixation protocol for transmission electron microscopy: An alternative to spend less time. Ultrastr Pathol 2009, 33(4):169-74.

24. Milazzo S, Russell N, Ernst E: Efficacy of homeopathic therapy in cancer treatment. Eur J Cancer 2006, 42:282-9.

25. Goldstein MS, Brown ER, Ballard-Barbash R, Morgenstern H, Bastani R, Lee J, Gatto N, Ambs A: The use of complementary and alternative medicine among california adults with and without cancer. Evid Based Complement Alternat Med 2005, 2(4):557-565.

26. Cooper EL: The Immune System and Complementary and Alternative Medicine. Evid Based Complement Alternat Med 2007, 4(S1):5-8.

27. Pascual-Carpe F, Vicente-Ortega V, Campos-Aranda M, Yañez-Gascón J: In vivo treatment of melanoma (B16F10) with a homeopathic agent and with a cytokine (IFN- $\alpha$ ). Oncol Res 2006, 16(5):211-216.
28. Es $S$, Kuttan $G, K c P$, Kuttan R: Effect of homeopathic medicines on transplanted tumors in mice. Asian Pac J Cancer Prev 2007, 8(3):390-4.

29. Burton JD, Ely S, Reddy PK, Stein R, Gold DV, Cardillo TM, Goldenberg DM: CD74 Is Expressed by Multiple Myeloma and Is a Promising Target for Therapy. Clin Cancer Res 2004, 10:6606-11.

30. Tucci MG, Lucarini G, Brancorsini D, Zizzi A, Pugnaloni A, Giacchetti A, Ricotti G, Biagini G: Involvement of E-cadherin, b-catenin, $\mathrm{Cdc} 42$ and CXCR4 in the progression and prognosis of cutaneous melanoma. Brit $J$ Dermatol 2007, 157:1212-16.

31. Ascierto PA, Kirkwood JM: Adjuvant therapy of melanoma with interferon: lessons of the past decade. J Transl Med 2008, 6:62.

32. Pikarsky $E$, Ben-Neriah Y: NF- $\kappa$ B inhibition: A double-edged sword in cancer? Eur J Cancer 2006, 42(6):779-84

33. Rivera J, Tessarollo L: Genetic Background and the Dilemma of Translating Mouse Studies to Humans. Immunity 2008, 28(1):1-4.

34. Overwijk WW, Restifo NP: B16 as a mouse model for human melanoma. Current Protocols in Immunology Wiley-Liss. New York 2001, Chapter 20(Unit 20.1)

35. Lotfi R, Schrezenmeier H, Lotze MT: Immunotherapy for cancer: promoting innate immunity. Front Biosci 2009, 14:818-32

36. Jiang $X$, Couchman JR: Perlecan and tumor angiogenesis. J Histochem Cytochem 2003, 51(11):1393-1410.

37. Jiang X, Multhaupt H, Chan E, Schaefer L, Schaefer RM, Couchman JR: Essential contribution of tumor-derived perlecan to epidermal tumor growth and angiogenesis. J Histochem Cytochem 2004, 52(12):1575-90.

38. Olsen BR: Life without perlecan has its problems. J Cell Biochem 1999, 147(5):909-12.

39. Smith CS, Gulobovskaya VM, Peck E, Xu LH, Monia BP, Yang X, Cance WG: Effect of focal adhesion kinase (FAK) downregulation with FAK antisense oligonucleotides and 5-fluorouracil on the viability of melanoma cell lines. Melanoma Res 2005, 15(5):357-62.

\section{Pre-publication history}

The pre-publication history for this paper can be accessed here: http://www.biomedcentral.com/1471-2407/10/113/prepub

doi:10.1186/1471-2407-10-113

Cite this article as: Guimarães et al:: In vitro and in vivo anticancer properties of a Calcarea carbonica derivative complex (M8) treatment in a murine melanoma model. BMC Cancer 2010 10:113.

\section{Submit your next manuscript to BioMed Central and take full advantage of:}

- Convenient online submission

- Thorough peer review

- No space constraints or color figure charges

- Immediate publication on acceptance

- Inclusion in PubMed, CAS, Scopus and Google Scholar

- Research which is freely available for redistribution

Submit your manuscript at www.biomedcentral.com/submit
Biomed Central 